\title{
Lymphocyte integration of complement cues
}

\author{
Ana V. Marin, Paula P. Cárdenas, Anaïs Jiménez-Reinoso, Miguel Muñoz-Ruiz ${ }^{1,2}$, \\ Jose R. Regueiro*,2
}

Department of Immunology, Ophthalmology and ENT, Complutense University School of Medicine and 12 de Octubre Health Research Institute (imas12), Madrid, Spain

\section{A R T I C L E I N F O}

\section{Article history:}

Received 14 December 2017

Accepted 8 February 2018

Available online xxx

\section{Keywords:}

Complement

Innate lymphoid cell

Lymphocyte

Signalling

Anaphylatoxins

Primary immunodeficiencies

\begin{abstract}
A B S T R A C T
We address current data, views and puzzles on the emerging topic of regulation of lymphocytes by complement proteins or fragments. Such regulation is believed to take place through complement receptors (CR) and membrane complement regulators (CReg) involved in cell function or protection, respectively, including intracellular signalling. Original observations in B cells clearly support that complement cues through CR improve their performance. Other lymphocytes likely integrate complement-derived signals, as most lymphoid cells constitutively express or regulate CR and CReg upon activation. CR-induced signals, particularly by anaphylatoxins, clearly regulate lymphoid cell function. In contrast, data obtained by CReg crosslinking using antibodies are not always confirmed in human congenital deficiencies or knock-out mice, casting doubts on their physiological relevance. Unsurprisingly, human and mouse complement systems are not completely homologous, adding further complexity to our still fragmentary understanding of complement-lymphocyte interactions.
\end{abstract}

(c) 2018 Elsevier Ltd. All rights reserved.

\section{Contents}

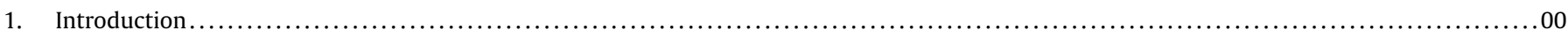

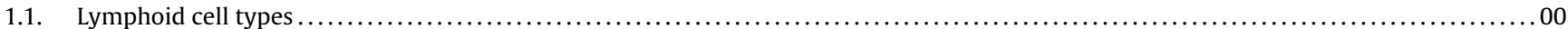

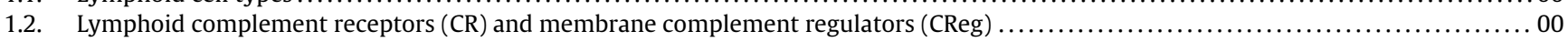

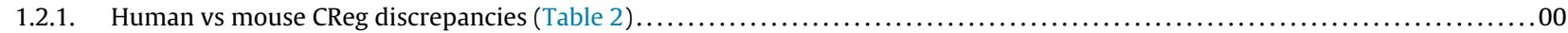

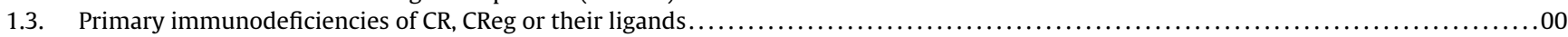

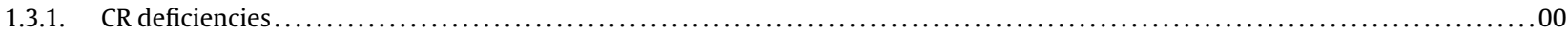

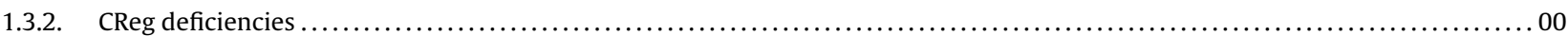

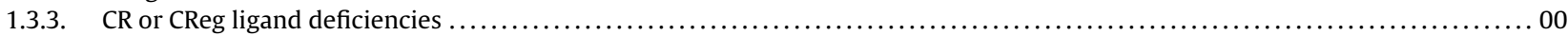

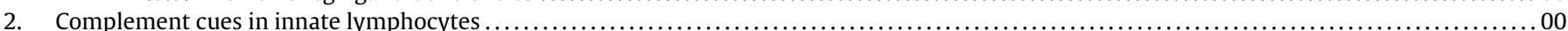

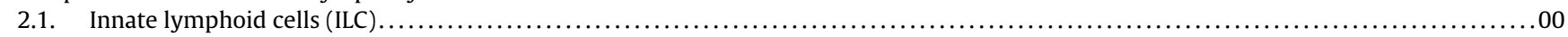

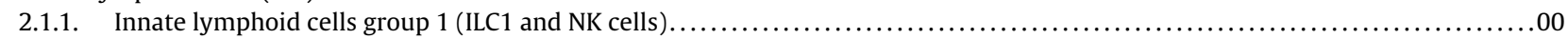

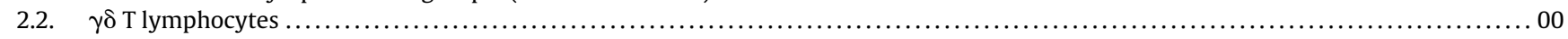

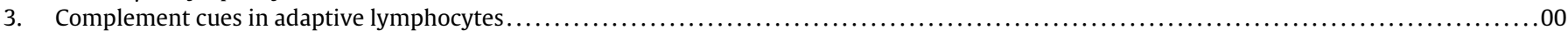

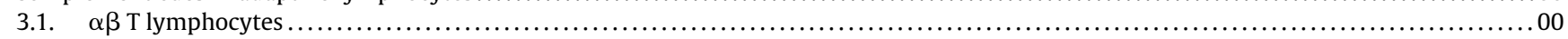

Abbreviations: aHUS, atypical haemolytic uremic syndrome; BCR, B-cell receptor; CTSL, cathepsin-L; CFP, complement factor P or properdin; CR, complement receptor;

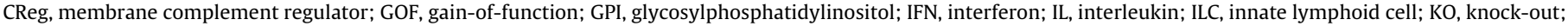

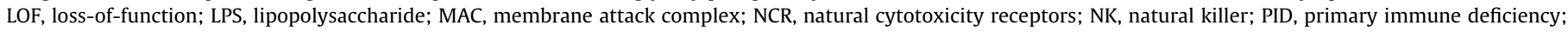

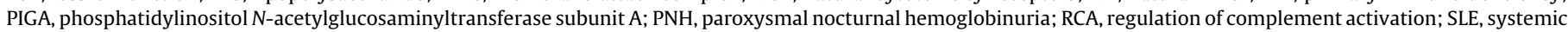
lupus erythematosus; Tc, cytolytic T cell; TCR, T-cell receptor; Th, helper T cell; TLR, toll-like receptor; TNF, tumor necrosis factor; Treg, regulatory T cell.

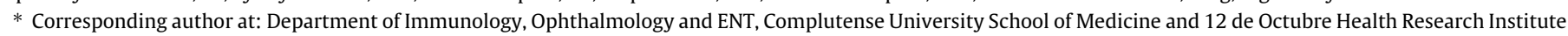
(imas12), 28040, Madrid, Spain.

E-mail address: regueiro@med.ucm.es (J.R. Regueiro).

1 Current address: The Francis Crick Institute, London NW1 1AT, United Kingdom.

2 Joint last authors. 


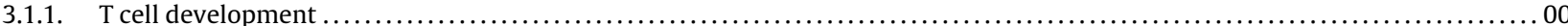

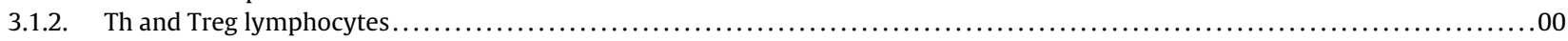

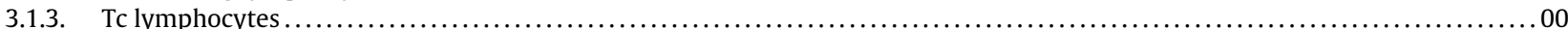

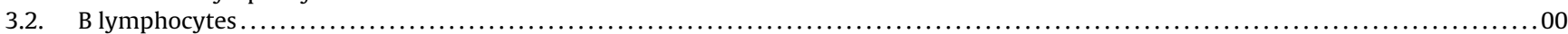

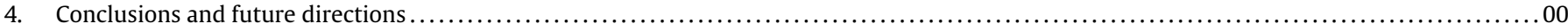

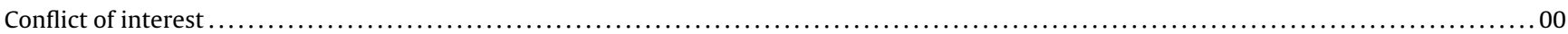

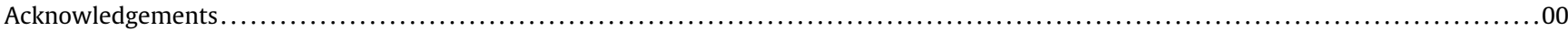

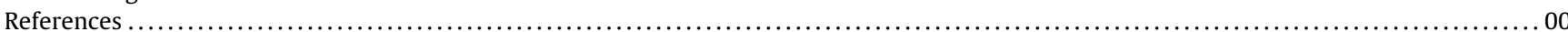

\section{Introduction}

The complement system is a complex network of glycoproteins that interact among them in a cascade fashion and with either non-self-molecules on pathogens and toxins or self-molecules on immune complexes and cells. The system is composed of more than 50 proteins, some of them soluble and produced by the liver mainly and others are membrane-bound, distributed in a wide range of cell types. Their aim is to identify and label for elimination foreign material informing surrounding cells through complement receptors $(\mathrm{CR})$, while remaining self-tolerant by means of soluble and membrane (CReg) complement regulators. To that end, complement activation can take place by three different routes: the classical, the lectin or the alternative pathway [1].

Certain cells receiving complement signals through CR can profoundly change their behaviour, as granulocytes do by triggering chemotaxis or phagocytosis in response to different complement fragments. Similarly, lymphoid cells such as B lymphocytes lower their B-cell receptor (BCR) activation threshold when their cognate antigen is opsonized by C3-derived fragments and detected by CR2. CReg involved in self-tolerance such as CD46 also show intriguing T lymphocyte regulation activities when engaged, although most of these activities have been revealed by antibody crosslinking rather than by complement engagement.

Complement regulation of lymphoid cell function has evolved humongously in the last decade, as information accumulates on the nature, signals and subset distribution of classic and new CR and CReg that perceive a growing range of complement proteins or fragments both extracellularly and intracellularly, since lymphocytes synthesize most soluble complement components [2]. Intracellular complement interactions, including the inflammosome, have led to the term 'complosome' [3]. Thus, it will be of substantial interest to investigate the complex interactions between the complosome and intracellular pathogens or inflammatory signals in a broad range of cells, and their impact on cell physiopathology.

Here we will review the range of CR and CReg used by lymphoid cells for the interpretation of direct complement cues, the human or animal models of complement deficiencies and their main consequences in lymphoid cell development or function. We have excluded indirect effects of complement in lymphoid cells through antigen presenting cells.

\subsection{Lymphoid cell types}

Lymphoid cells are normally classified as innate or adaptive depending on whether they rearrange antigen receptor (i.e. TCR or BCR) genes (Table 1, left). Under this classification, innate lymphoid cells (ILC) are clearly distinct from adaptive lymphoid cells (T and B lymphocytes). ILC comprise various types of bone-marrowderived tissue lymphocytes that contribute to immune responses to microbes and stressed cells, including tumour cells, and promote tissue repair. They are classified as group 1 (natural killer or NK cells and ILC1), group 2 (ILC2), and group 3 (ILC3 and lymphoid tissueinducer cells) depending on their cytokine and microbe recognition profile (Th1-like, Th2-like and Th17-like, respectively). Only NK cells are cytolytic. Besides their capacity to respond to and secrete cytokines, ILC express several cell surface receptors to recognize two types of relevant ligands: non-self-molecules from microbes and stress self-molecules on other cells. The biological significance of both receptors and ligands remains unclear, limiting our understanding of ILC biology.

Among T lymphocytes, $\gamma \delta$ T cells may be considered adaptive as they rearrange TCR genes. However, they may also be considered innate as they use their restricted TCR repertoire as pattern recognition receptors, rapidly secrete cytokines in response to infectious agents with rapid, innate-like responses that place them in the initiation phase of immune reactions. For the purpose of this review, we have thus considered them closer to innate lymphoid cells.

$\alpha \beta$ T lymphocytes derive from haematopoietic stem cells that colonize the thymus. Developing thymocytes undergo a series of maturation steps by interaction with thymic stromal cells, characterized by the expression of different cell surface markers such as CD4 and CD8. The former become Th lymphocytes, which are classified as effector (Th1, Th2 and Th17) or regulatory (Treg) depending on their functional profile, while the latter become cytolytic T lymphocytes (Tc), capable of specific cytolysis.

The generation and differentiation of B lymphocytes occurs in two steps that take place in different tissues. Firstly, B cell precursors differentiate into naïve B cells in the bone marrow, and, secondly, the immature B cells reach secondary lymphoid organs, where they mature into memory or effector cells [4].

\subsection{Lymphoid complement receptors (CR) and membrane complement regulators (CReg)}

CR and CReg expression levels are quite heterogeneous (- or + in Table 1) in different lymphoid cell types or subsets, and can be induced, increased or reduced after activation. Recently, other unexpected receptors have been reported (NKp46) [5]. Experiments designed to evaluate $\mathrm{CR} / \mathrm{CReg}$ roles include knock-out (KO) mice, human congenital deficiencies (due to loss-of-function or LOF mutations) or dysregulations (due to gain-of-function or GOF mutations) and triggering using either natural ligands (i.e. complement fragments) or antibodies. Therefore, the conclusions vary widely. In this review, we have considered genetic experiments and natural ligands as more reliable than antibody crosslinking.

Despite many unknowns (ND in Table 1), lymphocytes are well prepared to detect complement cues, because they express several $\mathrm{CR}$ or CReg on their surface, which are frequently up- or downregulated by activation.

\subsubsection{Human vs mouse CReg discrepancies (Table 2)}

The complement system is quite similar in humans and mice, but evolutionary gene rearrangements in their regulators of complement activation gene cluster has caused some notable differences affecting CReg, thus making comparisons difficult [46]. First, humans have single CD55 and CD59 genes whilst mice have two functional copies of $C d 55$ and $C d 59$, respectively, albeit with dif- 


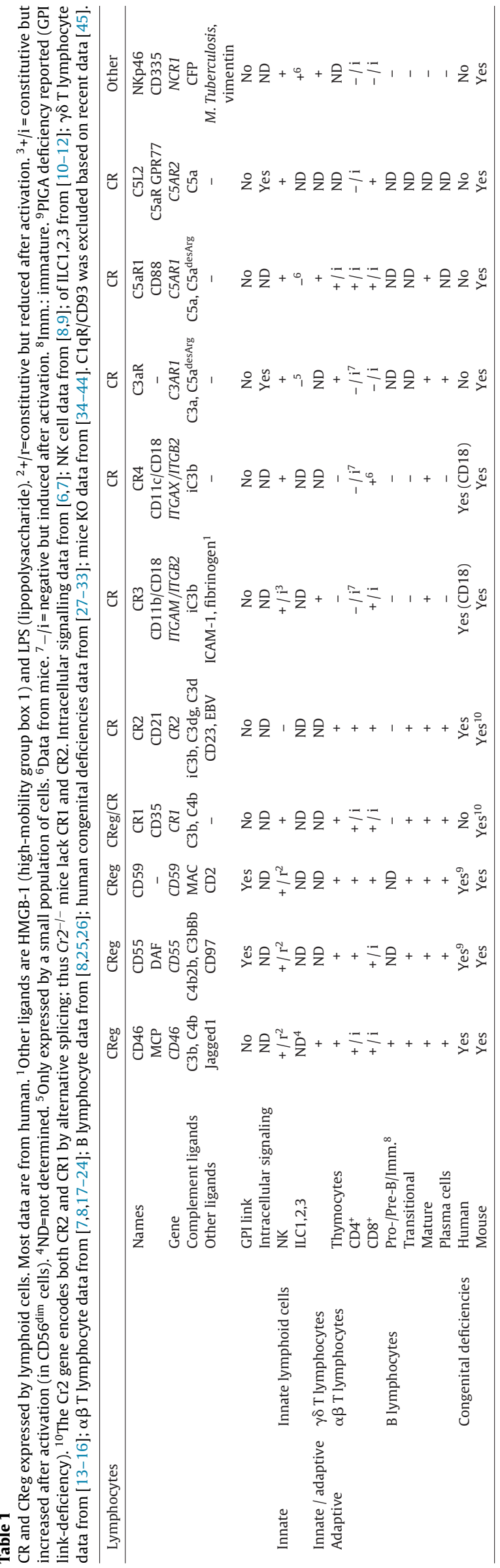

ferential tissue expression and/or structure [47,48]. Second, the functional murine homologue of CD46 is Crry, as rodent Cd46 is poorly expressed in leukocytes. Third, human CR1 and CR2 are encoded as splicing transcripts from a single $\mathrm{Cr} 2$ gene in mice [49].

\subsection{Primary immunodeficiencies of $C R, C R e g$ or their ligands}

Human primary immunodeficiencies (PID, [53]) have been reported for several CR, CReg or their ligands (see Table 1 ), offering the possibility to address if their lymphoid cells are affected. Patients show disparate clinical phenotypes as summarized below, essentially similar to their respective KO mouse models. Unlike CR, CReg protect cells from complement lysis, thus their deficiencies cause tissue damage.

\subsubsection{CR deficiencies}

$\mathrm{CR}$ show different functions ranging from immune complex clearance (CR1) or co-BCR activity (CR2), to phagocytosis (CR3, CR4) or inflammation (C3aR, C5aR1, C5L2). Therefore, their deficiencies are associated with disparate dysfunctions.

CR1 clears immune complexes due to its high affinity for C3b and $\mathrm{C} 4 \mathrm{~b}$, but it is also a CReg due to its decay-accelerating and cofactor activity for $\mathrm{C} 3 \mathrm{~b} / \mathrm{C} 4 \mathrm{~b}$ cleavage. Complete CR1 deficiency has not been reported, but reduced CR1 expression has been associated with autoimmune diseases such as glomerulonephritis [54] or systemic lupus erythematosus (SLE, [55]), in concordance with its immune complex clearance function.

As mentioned above, C3-opsonized antigens allow B lymphocytes to lower their BCR activation threshold for such antigens. Thus, complete CR2 deficiency is a mild PID reported in two adult patients to date $[27,30]$ that debuts with B cell dysfunction. Both exhibited hypogammaglobulinemia and impaired naïve to memory B cell differentiation, but unexpectedly normal antibody responses to protein vaccination. Recurrent infections were only present in one of them during early adulthood, but not in childhood.

Isolated CR3 or CR4 deficiencies have not been reported. These defects occur together with leukocyte adhesion deficiency type 1 , a severe PID caused by CD18 deficiency, shared by both CR and CD11a/CD18 or LFA-1. This PID is mainly characterized by recurrent bacterial infections, skin ulcers and impaired leukocyte adhesion to the vascular endothelium [56]. The role of CR3 + 4 deficiency in the clinical phenotype of CD18 deficiency is probably minor, as mouse models of LFA-1 deficiency recapitulate the human disorder.

Human C3aR, C5aR1 or C5aR2 (or C5L2) deficiencies have not been described. Only in vitro studies and KO mice have been reported, with a weak impact in lymphocyte biology.

Collectively, reported CR deficiencies do not show gross lymphocyte dysfunctions, except for CR2 deficiency, which is associated to impaired B lymphocyte development.

\subsubsection{CReg deficiencies}

CD46 deficiency is associated to atypical hemolytic uremic syndrome (aHUS). However, most severe CD46-deficient patients suffered from common variable immunodeficiency, which could be due to adaptive lymphocyte dysfunctions and recurrent chest infections [31]. In addition, CD46 mutations have been associated to other diseases such as preeclampsia or SLE [57].

Partial CD55 and/or CD59 deficiency are due to acquired somatic mutations in the phosphatidylinositol $\mathrm{N}$ acetylglucosaminyltransferase subunit A gene (PIGA), which encodes an enzyme required to synthesize the glycosylphosphatidylinositol (GPI) subunit for membrane GPI-anchored proteins, such as CD55 and CD59, affecting mostly erythrocytes in patients with paroxysmal nocturnal hemoglobinuria ( $\mathrm{PNH}$ ) [58]. However, complete congenital CD55 deficiency has been recently described in a small patient cohort with non-PNH clinical 
Table 2

Human and mouse CReg comparison. Adapted from [49-52]. MAC, membrane attack complex; FDC, follicular dendritic cell.

\begin{tabular}{|c|c|c|c|c|c|}
\hline Protein & Species & Gene & $\mathrm{kDa}$ & Function & Expression \\
\hline CD46 & Human & $C D 46$ & 60 & $\mathrm{C} 3 \mathrm{~b} / \mathrm{C} 4 \mathrm{~b}$ inactivating cofactor & Only nucleated cells \\
\hline Crry & Mouse & Cr1l & 65 & $\begin{array}{l}\mathrm{C} 3 \mathrm{~b} / \mathrm{C} 4 \mathrm{~b} \text { inactivating cofactor and C3 } \\
\text { convertase decay-accelerating activity }\end{array}$ & All cell types, including erythrocytes \\
\hline CD46 & Mouse & Cd46 & 60 & Involved in sperm acrosome reaction & Testis \\
\hline CD55 & Human & CD55 & 70 & C3/C5 convertases decay-accelerating activity & All cell types, including erythrocytes \\
\hline CD55 & Mouse & $C d 55 a, b$ & 70 & C3/C5 convertases decay-accelerating activity & All cell types, including erythrocytes \\
\hline CD59 & Human & CD59 & 20 & $\begin{array}{l}\text { Inhibits MAC (membrane attack complex), } \\
\text { preventing host cell lysis }\end{array}$ & All cell types, including erythrocytes \\
\hline CD59 & Mouse & $C d 59 a, b$ & 20 & $\begin{array}{l}\text { Inhibits MAC (membrane attack complex), } \\
\text { preventing host cell lysis }\end{array}$ & All cell types, including erythrocytes \\
\hline CR1 & Human & CR1 & $180-280$ & $\begin{array}{l}\text { Binds } \mathrm{C} 3 \mathrm{~b} / \mathrm{iC} 3 \mathrm{~b} \text { and } \mathrm{C} 3 \mathrm{~b} / \mathrm{C} 4 \mathrm{~b}-\text { opsonized } \\
\text { particles } \mathrm{C} 3 \mathrm{~b} / \mathrm{C} 4 \mathrm{~b} \text { inactivating cofactor and } \\
\mathrm{C} 3 / \mathrm{C} 5 \text { convertases decay-accelerating activity }\end{array}$ & $\begin{array}{l}\text { T cells, B cells, phagocytes, FDC, erythrocytes, } \\
\text { glomerular podocytes }\end{array}$ \\
\hline CR1 & Mouse & $\mathrm{Cr} 2$ & 200 & $\begin{array}{l}\text { Binds } \mathrm{C} 3 \mathrm{~b} / \mathrm{iC} 3 \mathrm{~b} \text { and } \mathrm{C} 3 \mathrm{~b} / \mathrm{C} 4 \mathrm{~b} \text {-opsonized } \\
\text { particles } \mathrm{C} 3 / \mathrm{C} 5 \text { convertases decay-accelerating } \\
\text { activity }\end{array}$ & B cells and Folicular Dendritic Cells (FDC) \\
\hline CR2 & Human & CR2 & 145 & $\begin{array}{l}\text { Binds } \mathrm{iC} 3 \mathrm{~b} / \mathrm{C} 3 \mathrm{dg} / \mathrm{C} 3 \mathrm{~d} \text {-opsonized particles } \\
\text { Lowers BCR stimulation threshold }\end{array}$ & B cells and FDC \\
\hline CR2 & Mouse & $\mathrm{Cr} 2$ & 145 & $\begin{array}{l}\text { Binds } \mathrm{iC} 3 \mathrm{~b} / \mathrm{C} 3 \mathrm{dg} / \mathrm{C} 3 \mathrm{~d} \text {-opsonized particles } \\
\text { Lowers BCR stimulation threshold }\end{array}$ & B cells and FDC \\
\hline
\end{tabular}

features. They showed complement hyperactivation, angiopathic thrombosis and early-onset protein-losing enteropathy, associated to recurrent infections in some of them [32]. In contrast, complete CD59 deficiency affects mostly red blood cells or neurons, causing chronic hemolysis and early-onset relapsing peripheral demyelinating disease resembling recurrent Guillain-Barré syndrome or chronic inflammatory demyelinating polyneuropathy [33,59].

Therefore, CReg deficiencies cause complement-dependent tissue damage, rather than lymphocyte dysfunctions.

\subsubsection{CR or CReg ligand deficiencies}

Congenital C3 deficiency can be classified as primary, due to LOF C3 mutations, or secondary to C3 convertase stabilization (GOF C3 mutations) or to LOF mutations in convertase regulators such as factor I or factor $\mathrm{H}$. C3-deficient patients are characterized by selective naïve to memory $\mathrm{B}$, but not $\mathrm{T}$ cell differentiation impairment [60] and by the development of recurrent pyogenic infections (mainly by Streptococcus pneumoniae and Neisseria meningitidis) than can be associated with immune complex diseases such as SLE or membranoproliferative glomerulonephritis [61]. Additionally, C3 mutations or polymorphisms have been linked with higher risk development of age-related macular degeneration [62], aHUS [63], dense deposit disease [64], and poor outcome in kidney [65] or liver [66] transplantation or vaccination [67].

C4 deficiency patients show SLE-like disorders and recurrent infections by encapsulated bacteria [68].

Primary C5 deficiency (which includes MAC deficiency) is mainly associated with severe and recurrent Neisseria infections such as meningitis and extragenital gonorrhea [69]. Secondary C5 deficiency is now common due to Eculizumab in PNH and aHUS patients, who develop similar clinical features [70].

Properdin or complement factor $\mathrm{P}$ (CFP) deficiency is an X-linked disorder associated with an increased susceptibility to Neisseria infections and sepsis [71].

Collectively, CR and CReg deficiencies cause susceptibility to bacterial infections and in the case of $\mathrm{C} 3$, impaired $\mathrm{B}$ lymphocyte development.

\section{Complement cues in innate lymphocytes}

\subsection{Innate lymphoid cells (ILC)}

Recently, interactions between the complement system and ILC have emerged, which may help to understand and thus manipu- late their responses, although their CR and CReg expression profile remains, except for NK cells, mostly undetermined (Table 1).

\subsubsection{Innate lymphoid cells group 1 (ILC1 and NK cells)}

It has been reported that CFP is a ligand for NKp46, a Natural Cytotoxicity Receptor (NCR), mainly expressed by NK cells and some subsets of mucosal ILC1 and ILC3. Patients lacking CFP are more susceptible to Neisseria meningitidis infection and CFP protection was dependent on NKp46 and ILC1 in mice (Fig. 1, left). Although CFP does not induce classical NK activation, it does promote their antibacterial activity through Chemokine ( $\mathrm{C}$ motif) ligand (XCL1) [21]. These data suggest that a) ILC and the alternative complement pathway collaborate against bacterial infection and b) complement-binding receptors in ILC may regulate their functions. Indeed, the NCR NKp46 and NKp30 are physically associated with CD59, which could signal through them upon antibody engagement, and induce enhanced cytolysis when cross-linked (Fig. 1, right). However, human CD59 deficiency does not associate to infections by herpesvirus, the main target of NK cells.

Human NK cells express most CR (Table 1). Interestingly, the main NK cell subsets (CD56 ${ }^{\text {dim }} \mathrm{CD} 16^{+}$, the most common and cytolytic, and CD56 ${ }^{\text {bright }} \mathrm{CD} 16^{-}$, their likely precursors) express different CR levels, high C3aR vs high CR4, respectively [9]. Indeed, pathogens and inflammation can regulate $C R$ expression levels: human CR3 is induced by lipopolysaccharide (LPS), interleukin (IL)15 , tumour necrosis factor (TNF)- $\alpha$, Poly (I:C) or serum, whereas CR4 is induced only by LPS or IL-15. C3aR expression is induced by Poly (I:C) and reduced by serum. C5aR1 and C5aR2 levels are reduced by Poly $(\mathrm{I}: \mathrm{C})$, whereas C5aR2 only by TNF- $\alpha$. C5aR1 is only expressed after inflammatory stimuli $[73,74]$. NK cells also express all tested CReg proteins to avoid complement-mediated membrane damage (Table 1 ), although significantly less than T cells [8,75], and in some cases at different levels in CD56 ${ }^{\text {dim }}$ vs CD56 ${ }^{\text {bright }}$ subsets (lower vs higher CD55, respectively). Cytokines, but not mitogens like phytohaemagglutinin, regulate NK CReg expression levels. For instance, IL-2 reduced CD46 and CD59, but not CD55, despite the fact that the last two are GPI-linked, whereas IL-15 increased all three CReg [75].

\section{2. $\gamma \delta$ T lymphocytes}

Information about $\gamma \delta$ T cells and surface $C R$ and $C R e g$ expression is still scarce (Table 1), as the putative contribution of complement signals to their functions. 


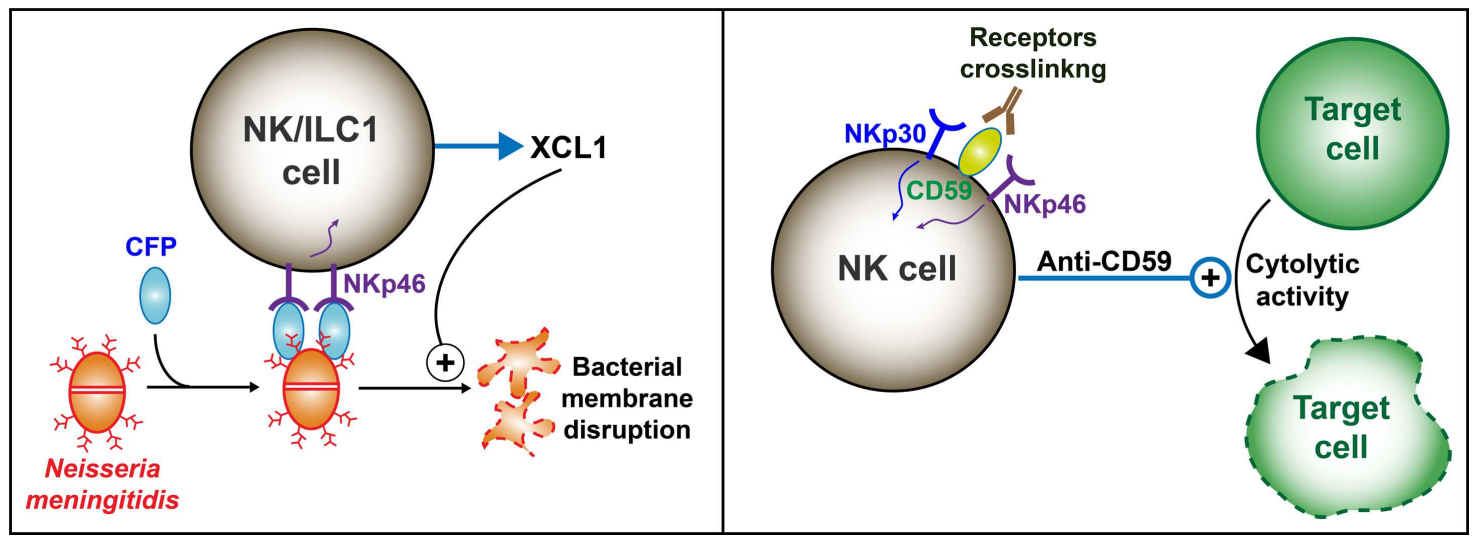

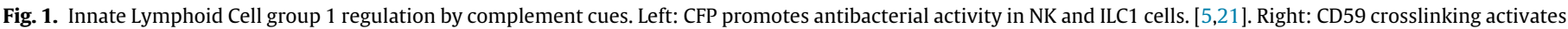
NK cell-mediated cytotoxicity [72]. Lines with a + indicate enhanced function.

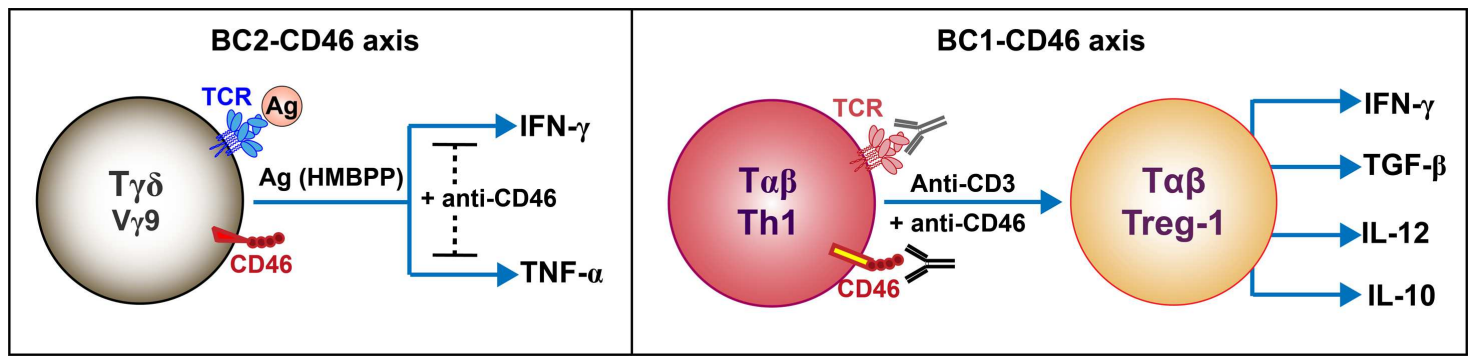

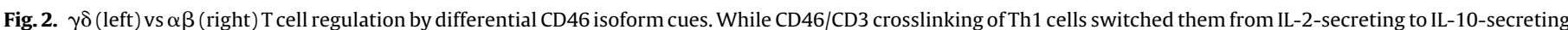

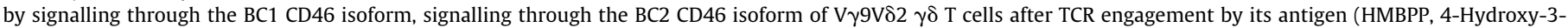

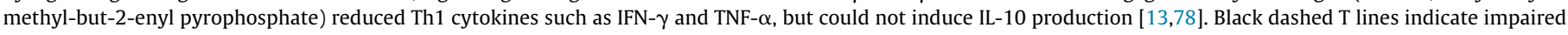
cytokine production.

It was proposed that during age-related macular degeneration (AMD) pathogenesis, the inadequate control of complement-driven inflammation results in the generation of the anaphylatoxin C5a, which recruits IL-17-producing T cells to the eye via C5aR [76]. The IL-17 released in the eye could generate an increase in vascular endothelial growth factor production, augmenting choroidal neovascularization (CNV), which would finally lead to loss of vision. In murine CNV, $\gamma \delta$ rather than $\alpha \beta$ T cells secrete the IL-17 detected in damaged eyes, and antibodies or antagonists disrupting the C5/C5a-C5aR axis completely prevented the rise of eye IL-17 and $\gamma \delta \mathrm{T}$ cells, supporting the hypothesis that C5a contributes to the recruitment of $\mathrm{C} \mathrm{aR} \mathrm{R}^{+} \gamma \delta \mathrm{T}$ cells in the eye [76].

CReg proteins such as CD46 have been reported to regulate the major human peripheral blood $\gamma \delta \mathrm{T}$ cell subset $(\mathrm{V} \gamma 9 \mathrm{~V} \delta 2)$, which normally shows a Th1-like cytokine profile. $\alpha \beta$ T cells express a variable pattern of CD46 cytoplasmic domain splicing isoforms including $\mathrm{BC} 1$, which is involved in their differentiation from interferon gamma (IFN)- $\gamma$-secreting Th1 cells into IL-10-secreting Treg type 1 (Treg-1) cells after TCR/CD46 co-engagement (Fig. 2, right). In contrast, $\mathrm{V} \gamma 9 \mathrm{~V} \delta 2 \gamma \delta \mathrm{T}$ cells expressed only the BC2 CD46 isoform, which inhibited its Th1-like cytokine profile but was unable to induce IL-10 secretion after stimulation with their specific phosphoantigen and anti-CD46 (Fig. 2, left). Thus, CD46 seems to use two distinct mechanisms to regulate the production of proinflammatory cytokines in $\gamma \delta$ vs $\alpha \beta$ T cells [77].

\section{Complement cues in adaptive lymphocytes}

\section{1. $\alpha \beta$ T lymphocytes}

\subsubsection{T cell development}

Patients carrying mutations in the central C3 component do not show overt thymus abnormalities, $\alpha \beta$ T-cell dependent infections or peripheral $\alpha \beta$ T cell subset alterations [60]. Indeed, complement levels are likely lower in the thymus than in peripheral blood [79]. However, the expression of certain CR such as CR2 is developmentally regulated in $\mathrm{T}$ cells, from high in early progenitors to low in mature thymocytes [80]. In neonates and children, CR2 is highly expressed in naïve $\mathrm{CD}^{+} \mathrm{T}$ cells just emerged from the thymus, decreasing with age [81], thus it has been proposed as a marker of thymus function.

\subsubsection{Th and Treg lymphocytes}

The use of agonist or antagonist monoclonal antibodies against CR or CReg expressed on T cells has yielded rich insights on their role in Th or Treg regulation, although the physiological relevance of this approach has not been always validated using their natural ligands, and congenital human deficiencies seldom support the conclusions.

The anaphylatoxins C3a and C5a have been shown to be strong $\alpha \beta$ T cell modulators. Indeed, $\alpha \beta$ T cells from C3aR1 and C5aR1 double KO mice showed strong iTreg cytokine responses [82] (Fig. 3 top). Indeed, in allogeneic responses, genetic deficiency or pharmacological blockade of $\mathrm{C} 3 \mathrm{aR} / \mathrm{C} 5 \mathrm{aR}$ signalling augments murine and human induced Treg generation, limiting the clinical expression of graft-versus-host disease [83]. However, many of the reported results may be indirect, due to other cell types responding to complement cues, e.g. signalling through C5aR and several toll-like receptors (TLR) to drive Th17 differentiation [84]. Later it was confirmed in a mouse model that macrophages are central for such C5a-dependent Th17 differentiation of self-reactive $\mathrm{T}$ cells that mediate autoimmune arthritis [85].

CD55, like CD46, protects T cells from complement lysis, but upon crosslinking it induced intracellular phosphorylation activation events and thus may act as a TCR co-receptor [87]. This was explored in mouse [86] and human [32] T cells lacking CD55 (Fig. 3, bottom). TCR engagement by antigen or antibodies increased Th1 


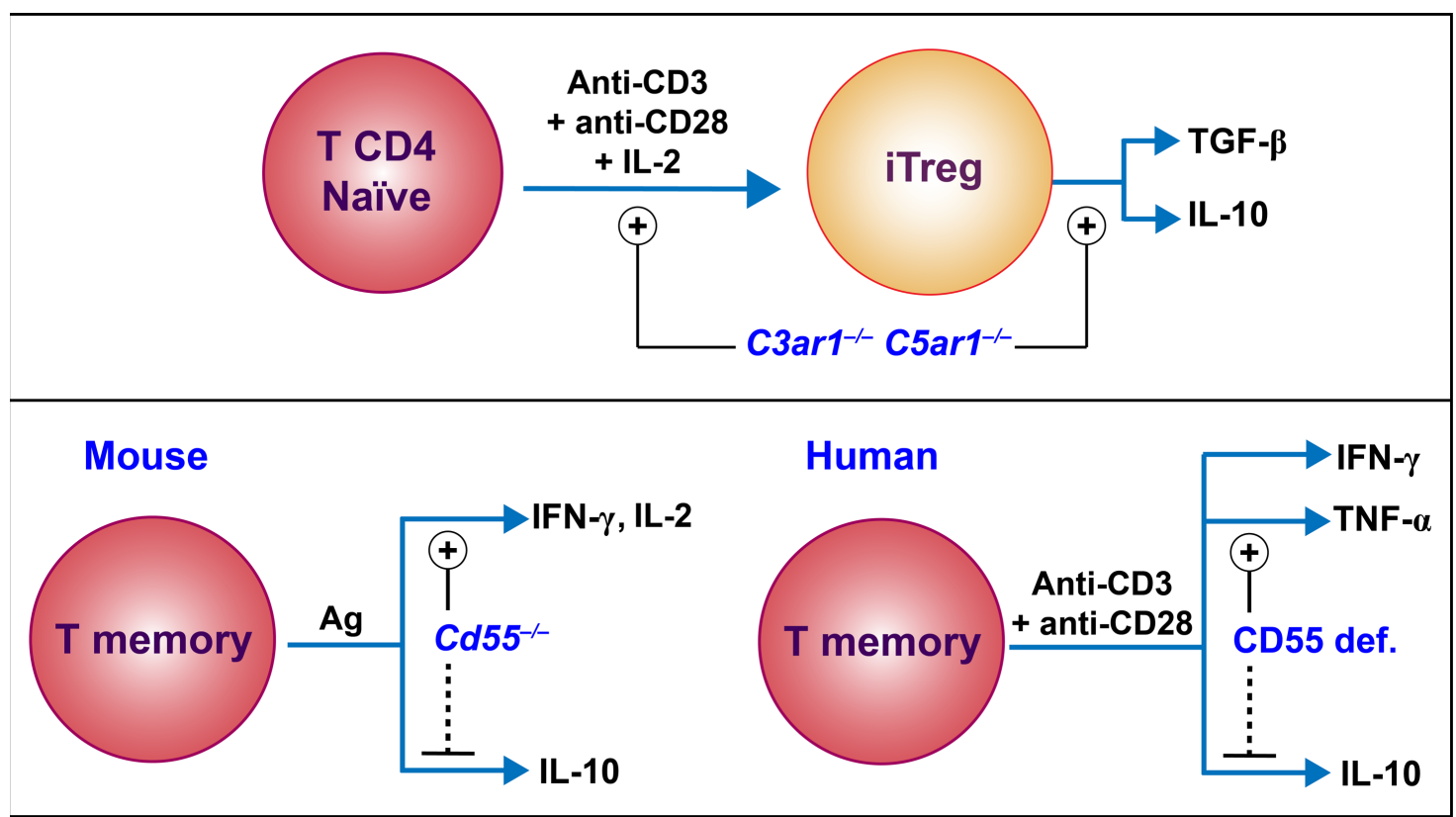

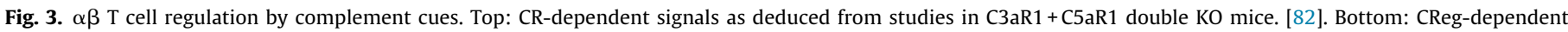

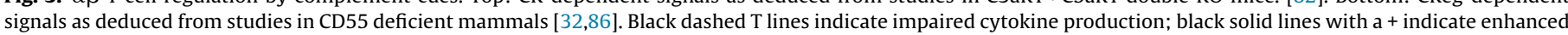
differentiation or cytokine production.

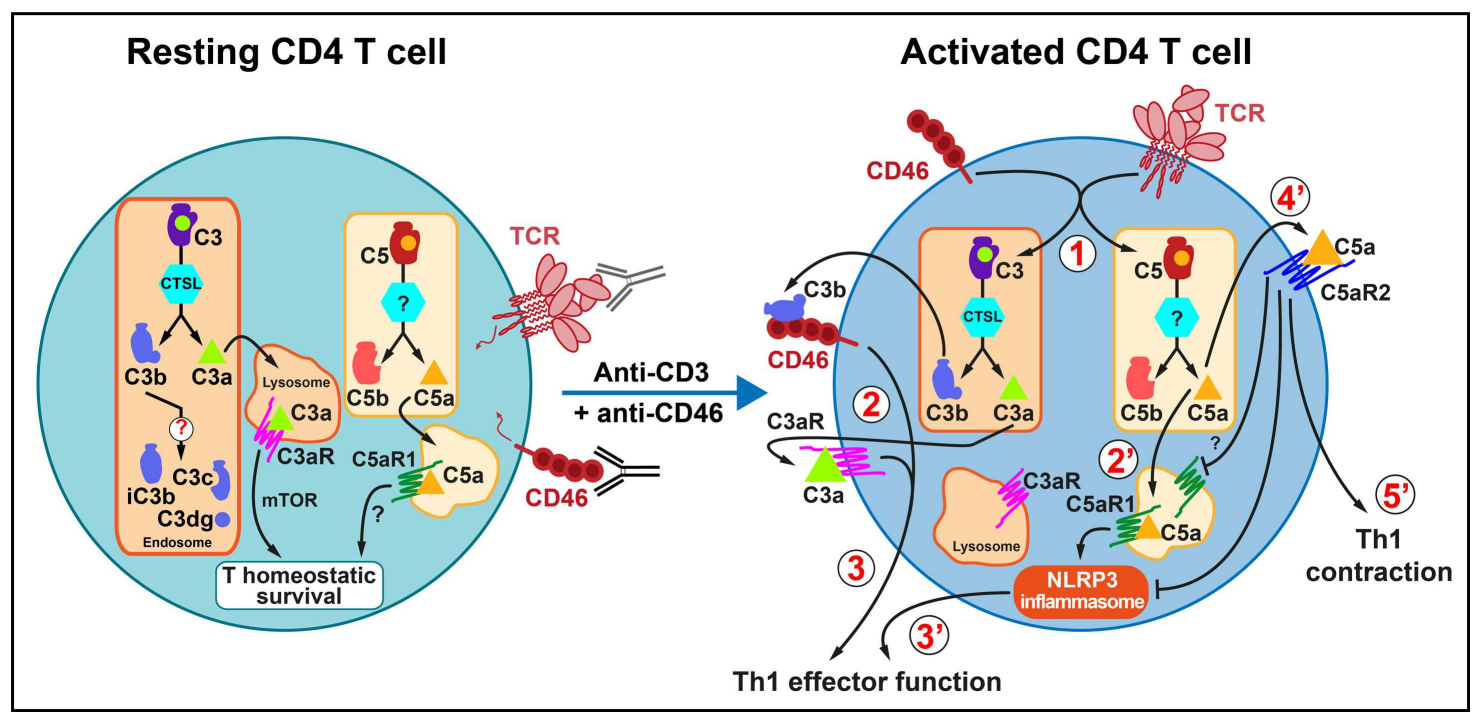

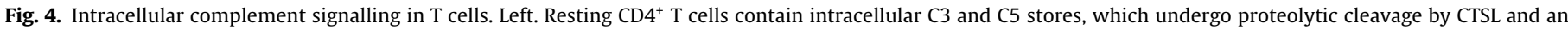

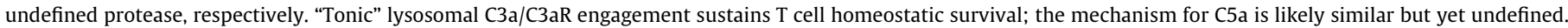

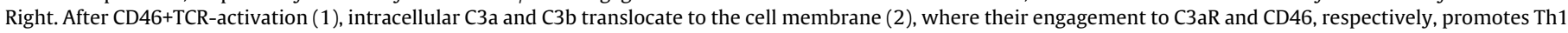

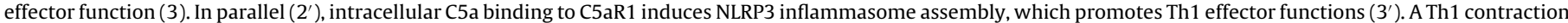
response $\left(5^{\prime}\right)$ may ensue by extracellular C5a binding to C5aR2 $\left(4^{\prime}\right)$ in the cell membrane [6,7].

cytokines such as IFN- $\gamma$ and IL-2 in mice or TNF- $\alpha$ (but not IFN$\gamma$ ) in humans, and decreased Treg cytokines such as IL-10 in both species. Therefore, CD55 signalling likely impacts effector T cell differentiation.

Recently, intracellular C3 (iC3) and C5 activation mechanisms were reported that might in part explain some of these findings. Indeed, iC3 activation by cathepsin-L (CTSL) was shown to be crucial for T cell survival and for T cell differentiation after TCR and CD46 activation (Fig. 4). Secreted intracellular C3a and C3b promote T cell survival through their surface receptors (C3aR and CD46, respectively) (Fig. 4, left). On the other hand, $\mathrm{CD}_{4}^{+} \mathrm{T}$ cells from C3deficient patients or $\mathrm{C} 3 \mathrm{KO}$ mice are unable to induce a normal Th1 response, probably because they cannot generate T-cell derived C3a and C3b [88,89]. This supports an autocrine loop of C3 fragments binding CD46 and C3aR for Th1 responses to occur. In addition, the co-engagement of TCR with CD46 induces the production of Th1 cytokines such as IFN- $\gamma$ [78] (Fig. 4, right). Lending support to this notion, inhibiting the protease CTSL impairs IFN- $\gamma$ after TCR/CD46 co-triggering [6], and CD46-deficient patients and patients with hypomorphic mutations in the gene encoding Jagged1 (a physiological ligand for CD46), showed impaired Th1 responses [90,91]. However, our recent data on congenital C3-deficient patients do not support gross Th subset derangements [60], and C3 or CD46 deficient patients do not resemble interferonopathies [92].

In turn, TCR and CD46 signalling generates iC5a that binds to intracellular C5aR1, leading to nucleotide-binding domain, leucine- 


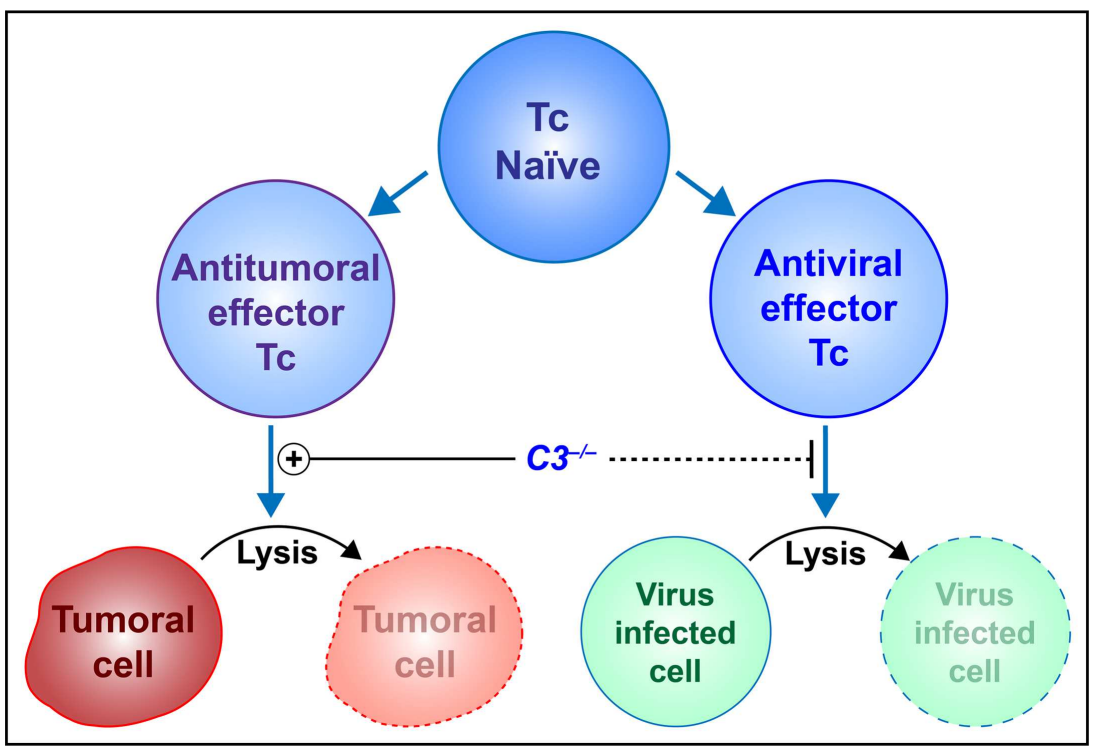

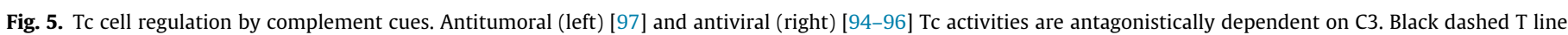
indicates impaired lysis; black solid line with a+ indicates enhanced lysis.

rich repeat family, pyrin domain containing 3 (NLRP3) assembly and Th1 induction, whereas secreted intracellular C5a binds to surface C5aR2, negatively regulating this mechanism [7]. Again, C5deficient patients do not show obvious T cell-dependent diseases.

In this context, other groups have reported that TCR/CD46 coengagement in $\mathrm{CD} 4^{+} \mathrm{T}$ cells switches Th1 into Treg differentiation (Fig. 2) [13], thus inhibiting Mycobacterium-specific $\alpha \beta$ and $\gamma \delta \mathrm{T}$ cells [93].

\subsubsection{Tc lymphocytes}

Although less studied than Th cells, complement has also been involved in Tc $\left(\mathrm{CD}^{+}\right)$cell activation and differentiation, but the mechanisms remain unclear. For instance, C3 KO mice, but not CR1/CR2 KO mice, showed poor Tc responses and high susceptibility to infection with influenza virus [94], as well as poor expansion of lymphocytic choriomeningitis virus -specific effector Tc cells in an epitope-dependent fashion [95]. Subsequent studies indicated that $\mathrm{C} 5 \mathrm{a}$ also plays a role in the generation of Tc cell responses, because a $\mathrm{C} 5 \mathrm{aR}$ antagonist prevented the generation of a proper response in influenza-infected mice (Fig. 5, right) [96].

In contrast, C3 KO mice tumour-infiltrating Tc lymphocytes improve resistance to tumor development in a T-cell- and IL10dependent manner (Fig. 5, left) [97]. The authors conclude that C3aR (and C5aR) may be a novel class of immune checkpoints that could be targeted for tumour immunotherapy.

Together, these results suggest that C 3 aR may enhance or inhibit Tc effector activity depending on the pathological context.

\subsection{B lymphocytes}

B lymphocyte regulation by complement is directly linked to its opsonizing, rather than inflammatory, function [98], mainly through CR2 (Table 1). CR2 is expressed mainly in mature B lymphocytes as part of the B-cell co-receptor complex, which includes CD19, CD81 and CD225. Upon engagement, this complex lowers the BCR activation threshold more than 1,000-fold [99] and enhances antigen processing and presentation to T cells [100]. Interestingly, anergic (i.e., self-tolerant) B cells also lower their BCR activation threshold when co-triggered by $\mathrm{C} 3 \mathrm{~d}(\mathrm{~g})$-opsonized self-antigens, which may give rise to autoimmune responses in mice [101]. This was the case in collagen-induced arthritis, which could be amelio- rated by C3 depletion [102], and in the mouse model for multiple sclerosis [103].

Most of these studies approaching the role of complement in $B$ cell differentiation and function were based on mouse models [109], but human CR2 deficiency (see above) also showed suboptimal BCR costimulation, impaired naïve to memory B cell differentiation and hypogammaglobulinemia (Fig. 6) $[27,30]$. Unexpectedly, antibody responses to protein or polysaccharide vaccination were normal or moderately impaired, respectively. Lack of CR2 ligands as observed in human C3 deficiency, whether primary or secondary mutations $[60,104]$ caused similar features (except hypogammaglobulinemia), indicating that CR2-mediated signals are critical for normal B cell differentiation, but not for specific antibody responses in humans (Fig. 6).

C4-binding protein (C4BP) functions as a complement regulator that acts as a factor I cofactor or accelerates the decay of the classical and the lectin pathways $\mathrm{C} 3 / \mathrm{C} 5$ convertases. It has also been reported to bind the costimulator protein $\mathrm{CD} 40$ on $\mathrm{B}$ cells [110], although more recent work failed to confirm the C4BP/CD40 interaction [111]. Interestingly, CD46/CD40 crosslinking inhibited CD40-mediated induction of surface CD23 and IL-4-dependent IgE isotype switching, suggesting that CD46 can reduce CD40 signalling [112].

Taken together, these findings support a strong impact of complement in B cell ontogeny and function, often associated to B cell-related diseases when complement is dysregulated.

\section{Conclusions and future directions}

In addition to their traditional role as microbe and immune complex identification and elimination, complement proteins, receptors and regulators have specific roles in the ontogeny and function of different cell types, including both innate and adaptive lymphocytes. Signals through complement-binding surface molecules such as CR or CReg improve lymphocyte responses, adapting them to environmental changes or inflammatory states, as shown for CFP and NKp46 in mouse ILC1. In addition, lymphocytes show differential subset-specific $\mathrm{CR}$ and $\mathrm{CReg}$ expression patterns and regulate their surface expression levels after activation, lending further support to their role in immunity. Unravelling the underlying mechanisms that drive these processes will help to understand 


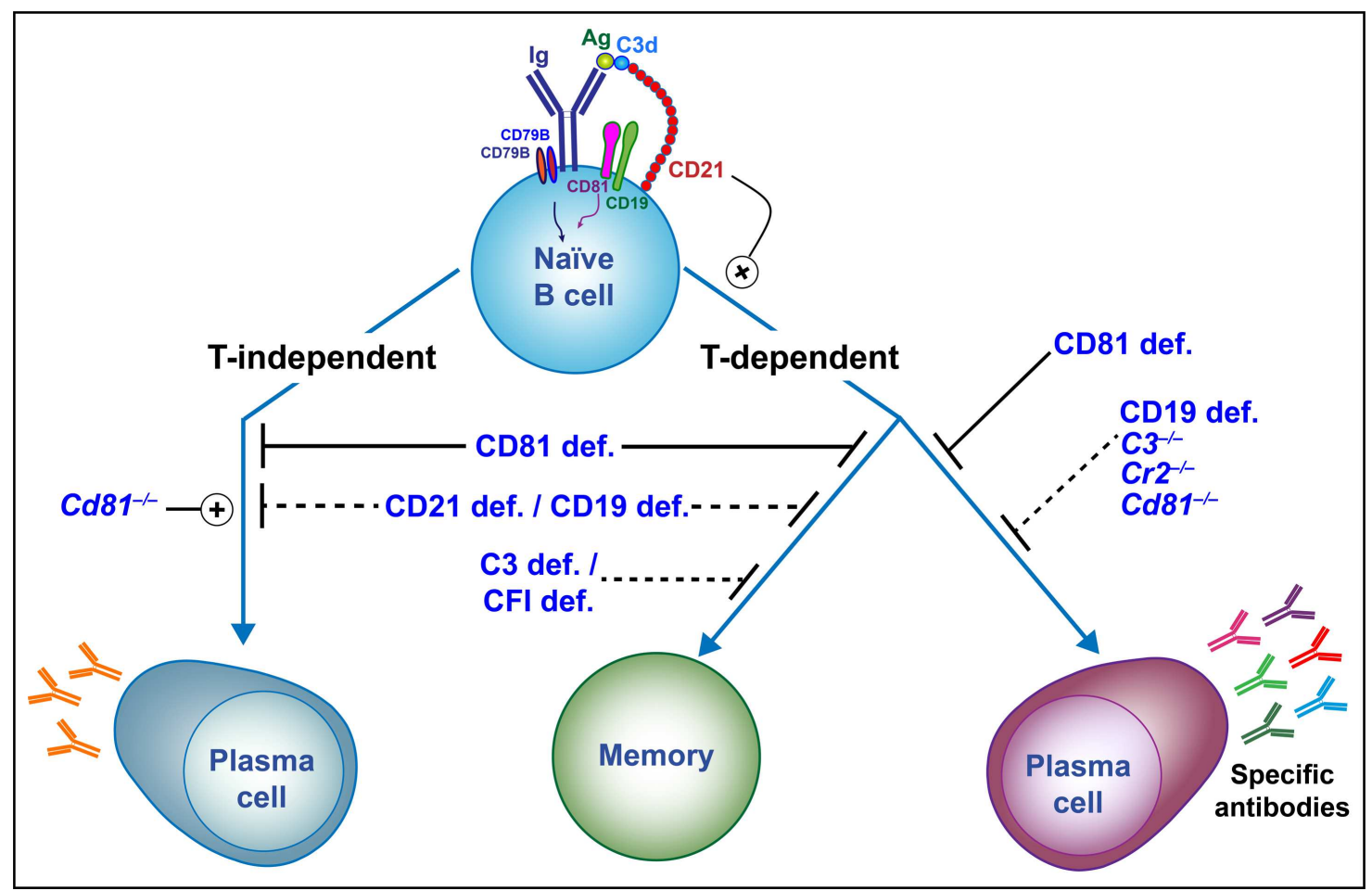

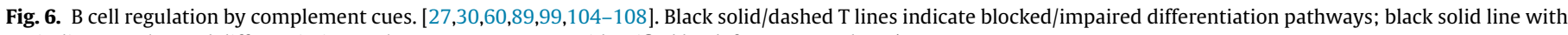
$\mathrm{a}+$ indicates enhanced differentiation pathway. Human PID are identified by def., mouse KO by $-/-$.

better the immune mechanisms triggering lymphocyte development and homeostasis.

Although truly physiological studies are scarce, CR such as anaphylatoxin receptors C3aR and C5aR or CR2, and CReg such as CD46 and CD55 can enhance or inhibit certain Th, Treg and Tc responses. In contrast, several studies clearly support that B lymphocytes are regulated by $\mathrm{CR}$, as shown for memory $\mathrm{B}$ cell differentiation, which is impaired when CR2 or its C3-derived ligands are absent.

While complement studies are re-emerging in the last years due to these new roles in lymphocyte biology, further work is warranted to define their specific roles in each lymphocyte subset. To that end, mouse models are useful but insufficient for nonhomologous human CR or CReg. In those cases, careful studies in human PID and cell lines thereof are required to fully understand the role of extracellular and intracellular complement (the complosome) in lymphocyte physiopathology and the functional connection between complement and others processes in a broader range of cells and activities.

\section{Conflict of interest}

All authors declare that they have no relevant conflicts of interest.

\section{Acknowledgements}

This work was supported by the Ministerio de Economía y Competitividad (MINECO) grant SAF2014-54708-R and Comunidad Autónoma de Madrid (CAM Ref. B2017/BMD3673). AVM was supported by Complutense/Harvard University (CT46/15); AJR by MINECO (FPI BES-2012-055054) and EFIS-IL (EFIS-IL Short-Term Fellowship); PPC by MINECO (152JA19262); MMR by Complutense University and The Francis Crick Institute.

\section{References}

[1] D. Ricklin, G. Hajishengallis, K. Yang, J.D. Lambris, Complement: a key system for immune surveillance and homeostasis, Nat. Immunol. 11 (9) (2010) 785-797, http://dx.doi.org/10.1038/ni.1923.

[2] S. Freeley, C. Kemper, G. Le Friec, The "ins and outs" of complement-driven immune responses, Immunol. Rev. 274 (1) (2016) 16-32, http://dx.doi.org/ 10.1111/imr.12472.

[3] G. Arbore, C. Kemper, M. Kolev, Intracellular complement - the complosome - in immune cell regulation, Mol. Immunol. 89 (2017) 2-9, http://dx.doi.org/ 10.1016/j.molimm.2017.05.012.

[4] L.J. McHeyzer-Williams, M.G. McHeyzer-Williams, Antigen-specific memory B cell development, Annu. Rev. Immunol. 23 (2005) 487-513, http://dx.doi. org/10.1146/annurev.immunol.23.021704.115732.

[5] E. Narni-Mancinelli, L. Gauthier, M. Baratin, S. Guia, A. Fenis, A.E. Deghmane, B. Rossi, P. Fourquet, B. Escaliere, Y.M. Kerdiles, S. Ugolini, M.K. Taha, E. Vivier, Complement factor $\mathrm{P}$ is a ligand for the natural killer cell-activating receptor NKp46, Sci. Immunol. 2 (10) (2017), http://dx.doi.org/10.1126/ sciimmunol.aam9628.

[6] M.K. Liszewski, M. Kolev, G. Le Friec, M. Leung, P.G. Bertram, A.F. Fara, M. Subias, M.C. Pickering, C. Drouet, S. Meri, T.P. Arstila, P.T. Pekkarinen, M. Ma, A. Cope, T. Reinheckel, S. Rodriguez de Cordoba, B. Afzali, J.P. Atkinson, C. Kemper, Intracellular complement activation sustains $\mathrm{T}$ cell homeostasis and mediates effector differentiation, Immunity 39 (6) (2013) 1143-1157, http://dx.doi.org/10.1016/j.immuni.2013.10.018.

[7] G. Arbore, E.E. West, R. Spolski, A.A. Robertson, A. Klos, C. Rheinheimer, P. Dutow, T.M. Woodruff, Z.X. Yu, L.A. O’Neill, R.C. Coll, A. Sher, W.J. Leonard, J. Kohl, P. Monk, M.A. Cooper, M. Arno, B. Afzali, H.J. Lachmann, A.P. Cope, K.D. Mayer-Barber, C. Kemper, T helper 1 immunity requires complement-driven NLRP3 inflammasome activity in CD4(+) T cells, Science (N. Y., N.Y.) 352 (6292) (2016) aad1210, http://dx.doi.org/10.1126/science.aad1210.

[8] S.E. Christmas, C.T. de la Mata Espinosa, D. Halliday, C.A. Buxton, J.A Cummerson, P.M. Johnson, Levels of expression of complement regulatory proteins CD46, CD55 and CD59 on resting and activated human peripheral blood leucocytes, Immunology 119 (4) (2006) 522-528, http://dx.doi.org/ 10.1111/j.1365-2567.2006.02467.x.

[9] X. Min, C. Liu, Y. Wei, N. Wang, G. Yuan, D. Liu, Z. Li, W. Zhou, K. Li, Expression and regulation of complement receptors by human natural killer cells, Immunobiology 219 (9) (2014) 671-679, http://dx.doi.org/10.1016/j. imbio.2014.03.018.

[10] K.M. Quell, C.M. Karsten, A. Kordowski, L.N. Almeida, D. Briukhovetska, A.V. Wiese, J. Sun, F. Ender, K. Antoniou, T. Schroder, I. Schmudde, J.L. Berger, P. Konig, T. Vollbrandt, Y. Laumonnier, J. Kohl, Monitoring C3aR expression using a floxed tdTomato-C3aR reporter knock-in mouse, J. Immunol. (Baltimore, Md. 1950) 199 (2) (2017) 688-706, http://dx.doi.org/10.4049/ jimmunol.1700318. 
[11] F. Ender, A.V. Wiese, I. Schmudde, J. Sun, T. Vollbrandt, P. Konig, Y. Laumonnier, J. Kohl, Differential regulation of C5a receptor 1 in innate immune cells during the allergic asthma effector phase, PloS One 12 (2) (2017) e0172446, http://dx.doi.org/10.1371/journal.pone.0172446.

[12] A. Reynders, N. Yessaad, T.P. Vu Manh, M. Dalod, A. Fenis, C. Aubry, G. Nikitas, B. Escaliere, J.C. Renauld, O. Dussurget, P. Cossart, M. Lecuit, E. Vivier, E. Tomasello, Identity, regulation and in vivo function of gut NKp46+RORgammat+ and NKp46+RORgammat- lymphoid cells, EMBO J. 30 (14) (2011) 2934-2947, http://dx.doi.org/10.1038/emboj.2011.201.

[13] J. Cardone, G. Le Friec, P. Vantourout, A. Roberts, A. Fuchs, I. Jackson, T. Suddason, G. Lord, J.P. Atkinson, A. Cope, A. Hayday, C. Kemper, Complement regulator CD46 temporally regulates cytokine production by conventional and unconventional T cells, Nat. Immunol. 11 (9) (2010) 862-871, http://dx doi.org/10.1038/ni.1917.

[14] J.F. Hedges, K.J. Lubick, M.A. Jutila, Gamma delta T cells respond directly to pathogen-associated molecular patterns, J. Immunol. (Baltimore, Md. 1950) 174 (10) (2005) 6045-6053.

[15] G. Han, S. Geng, Y. Li, G. Chen, R. Wang, X. Li, Y. Ma, B. Shen, Y. Li, gammadeltaT-cell function in sepsis is modulated by C5a receptor signalling, Immunology 133 (3) (2011) 340-349, http://dx.doi.org/10.1111/j. 1365-2567.2011.03445.x.

[16] T.K. Connelley, C. Longhi, A. Burrells, K. Degnan, J. Hope, A.J. Allan, J.A Hammond, A.K. Storset, W.I. Morrison, NKp46+ CD3+ cells: a novel nonconventional T cell subset in cattle exhibiting both NK cell and T cell features, J. Immunol. (Baltimore, Md. 1950) 192 (8) (2014) 3868-3880, http://dx.doi.org/10.4049/jimmunol.1302464.

[17] M.L. Pekalski, A.R. Garcia, R.C. Ferreira, D.B. Rainbow, D.J. Smyth, M. Mashar J. Brady, N. Savinykh, X.C. Dopico, S. Mahmood, S. Duley, H.E. Stevens, N.M. Walker, A.J. Cutler, F. Waldron-Lynch, D.B. Dunger, C. Shannon-Lowe, A.J. Coles, J.L. Jones, C. Wallace, J.A. Todd, L.S. Wicker, Neonatal and adult recent thymic emigrants produce IL-8 and express complement receptors CR1 and CR2, JCI Insight 2 (16) (2017), http://dx.doi.org/10.1172/jci.insight.93739.

[18] S. Nataf, N. Davoust, R.S. Ames, S.R. Barnum, Human T cells express the C5a receptor and are chemoattracted to C5a, J. Immunol. (Baltimore, Md. 1950) 162 (7) (1999) 4018-4023.

[19] T. Werfel, K. Kirchhoff, M. Wittmann, G. Begemann, A. Kapp, F. Heidenreich, O. Gotze, J. Zwirner, Activated human T lymphocytes express a functional C3a receptor, J. Immunol. (Baltimore, Md. 1950) 165 (11) (2000) 6599-6605.

[20] C. Wagner, G.M. Hansch, S. Stegmaier, B. Denefleh, F. Hug, M. Schoels, The complement receptor 3, CR3 (CD11b/CD18), on T lymphocytes: activation-dependent up-regulation and regulatory function, Eur. J. Immunol. 31 (4) (2001) 1173-1180, http://dx.doi.org/10.1002/15214141(200104)31:43.0.CO;2-9.

[21] X. Zhuang, E.O. Long, Complement factor P: promoting the antibacterial activity of natural killer cells, Cell. Mol. Immunol. 14 (10) (2017) 797-799, http://dx.doi.org/10.1038/cmi.2017.60.

[22] A. Erdei, A. Isaak, K. Torok, N. Sandor, M. Kremlitzka, J. Prechl, Z. Bajtay, Expression and role of CR1 and CR2 on B and T lymphocytes under physiological and autoimmune conditions, Mol. Immunol. 46 (14) (2009) 2767-2773, http://dx.doi.org/10.1016/j.molimm.2009.05.181.

[23] M.L. Pekalski, A. Rubio Garcia, R.C. Ferreira, D.B. Rainbow, D.J. Smyth, M. Mashar, J. Brady, N. Savinykh, X. Castro Dopico, S. Mahmood, S. Duley, H.E. Stevens, N.M. Walker, A.J. Cutler, F. Waldron-Lynch, D.B. Dunger, C. Shannon-Lowe, A.J. Coles, J.L. Jones, C. Wallace, J.A. Todd, L.S. Wicker, Complement receptor 2 and IL-8 production identifies in adults and neonates naive $\mathrm{T}$ cells recently arising from the thymus, bioRxiv (2016) http://dx.doi.org/10.1101/059535.

[24] T. Rozmyslowicz, D.O. Conover, M.Z. Ratajczak, G.N. Gaulton, Role of C3a in regulating thymocyte infection by HIV-1, J. Clin. Path Lab Med. 1 (1) (2017) $1-5$.

[25] L. Ottonello, A. Corcione, G. Tortolina, I. Airoldi, E. Albesiano, A. Favre, R. D'Agostino, F. Malavasi, V. Pistoia, F. Dallegri, rC5a directs the in vitro migration of human memory and naive tonsillar B lymphocytes: implications for B cell trafficking in secondary lymphoid tissues, J. Immunol. (Baltimore, Md. 1950) 162 (11) (1999) 6510-6517.

[26] M. Kremlitzka, B. Macsik-Valent, A. Erdei, Regulation of B cell functions by Toll-like receptors and complement, Immunol. Lett. 178 (2016) 37-44, http://dx.doi.org/10.1016/j.imlet.2016.07.015.

[27] J. Thiel, L. Kimmig, U. Salzer, M. Grudzien, D. Lebrecht, T. Hagena, R. Draeger, N. Voelxen, A. Bergbreiter, S. Jennings, S. Gutenberger, A. Aichem, H. Illges, J.P. Hannan, A.K. Kienzler, M. Rizzi, H. Eibel, H.H. Peter, K. Warnatz, B. Grimbacher, J.A. Rump, M. Schlesier, Genetic CD21 deficiency is associated with hypogammaglobulinemia, J. Allergy Clin. Immunol. 129 (3)(2012) 801-810, http://dx.doi.org/10.1016/j.jaci.2011.09.027, e6

[28] Y. Nevo, B. Ben-Zeev, A. Tabib, R. Straussberg, Y. Anikster, Z. Shorer, A Fattal-Valevski, A. Ta-Shma, S. Aharoni, M. Rabie, S. Zenvirt, H. Goldshmidt, Y. Fellig, A. Shaag, D. Mevorach, O. Elpeleg, CD59 deficiency is associated with chronic hemolysis and childhood relapsing immune-mediated polyneuropathy, Blood 121 (1) (2013) 129-135, http://dx.doi.org/10.1182/ blood-2012-07-441857.

[29] F. Taghizade Mortezaee, B. Esmaeli, M. Badalzadeh, M. Ghadami, M.R. Fazlollahi, Z. Alizade, A.A. Hamidieh, Z. Chavoshzadeh, M. Movahedi, M. Heydarzadeh, M. Sadeghi Shabestari, M. Tavassoli, M. Nabavi, R. Nasiri Kalmarzi, Z. Pourpak, Investigation of ITGB2 gene in 12 new cases of leukocyte adhesion deficiency-type I revealed four novel mutations from Iran, Arch. Iran. Med. 18 (11) (2015) 760-764, doi: 0151811/aim.006.
[30] M.W. Wentink, A.J. Lambeck, M.C. van Zelm, E. Simons, J.J. van Dongen, I.J. H, E.H. Scholvinck, M. van der Burg, CD21 and CD19 deficiency: two defects in the same complex leading to different disease modalities, Clin. Immunol. (Orlando, Fla.) 161 (2) (2015) 120-127, http://dx.doi.org/10.1016/j.clim. 2015.08.010.

[31] M.K. Liszewski, J.P. Atkinson, Complement regulator CD46: genetic variants and disease associations, Hum. Genomics 9 (2015) 7, http://dx.doi.org/10. 1186/s40246-015-0029-z.

[32] A. Ozen, W.A. Comrie, R.C. Ardy, C. Dominguez Conde, B. Dalgic, O.F. Beser, A.R. Morawski, E. Karakoc-Aydiner, E. Tutar, S. Baris, F. Ozcay, N.K. Serwas, Y. Zhang, H.F. Matthews, S. Pittaluga, L.R. Folio, A. Unlusoy Aksu, J.J. McElwee, A. Krolo, A. Kiykim, Z. Baris, M. Gulsan, I. Ogulur, S.B. Snapper, R.H.J. Houwen, H.L. Leavis, D. Ertem, R. Kain, S. Sari, T. Erkan, H.C. Su, K. Boztug, M.J. Lenardo, CD55 deficiency, early-onset protein-losing enteropathy, and thrombosis, N. Engl. J. Med. 377 (1) (2017) 52-61, http://dx.doi.org/10.1056/ NEJMoa1615887.

[33] D. Ardicli, E.Z. Taskiran, C. Kosukcu, C. Temucin, K.K. Oguz, G. Haliloglu, M. Alikasifoglu, H. Topaloglu, Neonatal-onset recurrent Guillain-Barre syndrome-like disease: clues for inherited CD59 deficiency, Neuropediatrics 48 (6) (2017) 477-481, http://dx.doi.org/10.1055/s-0037-1604483.

[34] H. Lim, Y.U. Kim, S.M. Drouin, S. Mueller-Ortiz, K. Yun, E. Morschl, R.A. Wetsel, Y. Chung, Negative regulation of pulmonary Th17 responses by C3a anaphylatoxin during allergic inflammation in mice, PloS One 7 (12)(2012) e52666, http://dx.doi.org/10.1371/journal.pone.0052666.

[35] F. Wu, Q. Zou, X. Ding, D. Shi, X. Zhu, W. Hu, L. Liu, H. Zhou, Complement component C3a plays a critical role in endothelial activation and leukocyte recruitment into the brain, J. Neuroinflamm. 13 (2016) 23, http://dx.doi.org/ 10.1186/s12974-016-0485-y.

[36] Q. Peng, K. Li, L.A. Smyth, G. Xing, N. Wang, L. Meader, B. Lu, S.H. Sacks, W. Zhou, C3a and C5a promote renal ischemia-reperfusion injury, J. Am. Soc. Nephrol. JASN 23 (9) (2012) 1474-1485, http://dx.doi.org/10.1681/asn. 2011111072.

[37] I.V. Martin, A. Bohner, P. Boor, E. Shagdarsuren, U. Raffetseder, F. Lammert, J. Floege, T. Ostendorf, S.N. Weber, Complement C5a receptors C5L2 and C5aR in renal fibrosis, Am. J. Physiol. Renal Physiol. 314 (1) (2017) F35-F46, http://dx.doi.org/10.1152/ajprenal.00060.2017.

[38] V.V. Lyzogubov, P.S. Bora, X. Wu, L.E. Horn, R. de Roque, X.V. Rudolf, J.P. Atkinson, N.S. Bora, The complement regulatory protein CD46 deficient mouse spontaneously develops dry-type age-related macular degeneration-like phenotype, Am. J. Pathol. 186 (8) (2016) 2088-2104, http://dx.doi.org/10.1016/j.ajpath.2016.03.021.

[39] C. Fang, T. Miwa, W.C. Song, Decay-accelerating factor regulates T-cell immunity in the context of inflammation by influencing costimulatory molecule expression on antigen-presenting cells, Blood 118 (4) (2011) 1008-1014, http://dx.doi.org/10.1182/blood-2011-04-348474.

[40] P. Herrmann, J.A. Cowing, E. Cristante, S.E. Liyanage, J. Ribeiro, Y. Duran, L. Abelleira Hervas, L.S. Carvalho, J.W. Bainbridge, U.F. Luhmann, R.R. Ali, Cd59a deficiency in mice leads to preferential innate immune activation in the retinal pigment epithelium-choroid with age, Neurobiol. Aging 36 (9) (2015) 2637-2648, http://dx.doi.org/10.1016/j.neurobiolaging.2015.05.019.

[41] M.D. Neher, M.C. Rich, C.N. Keene, S. Weckbach, A.L. Bolden, J.T. Losacco, J. Patane, M.A. Flierl, L. Kulik, V.M. Holers, P.F. Stahel, Deficiency of complement receptors CR2/CR1 in Cr2(-)/(-) mice reduces the extent of secondary brain damage after closed head injury, J. Neuroinflamm. 11 (2014) 95, http://dx.doi.org/10.1186/1742-2094-11-95.

[42] A.C. Jacobson, K.M. Roundy, J.J. Weis, J.H. Weis, Regulation of murine splenic B cell CR3 expression by complement component 3, J. Immunol.(Baltimore, Md. 1950) 183 (6) (2009) 3963-3970, http://dx.doi.org/10.4049/jimmunol. 0900038.

[43] T.N. Ramos, D.C. Bullard, S.R. Barnum, Deletion of the complement phagocytic receptors CR3 and CR4 does not alter susceptibility to experimental cerebral malaria, Parasite Immunol. 34 (11) (2012) 547-550, http://dx.doi.org/10.1111/pim.12002.

[44] A. Glasner, H. Simic, K. Miklic, Z. Roth, O. Berhani, I. Khalaila, S. Jonjic, O. Mandelboim, Expression, function, and molecular properties of the killer receptor Ncr1-Noe, J. Immunol. (Baltimore, Md. 1950) 195 (8) (2015) 3959-3969, http://dx.doi.org/10.4049/jimmunol.1501234.

[45] M.C. Greenlee-Wacker, M.D. Galvan, S.S. Bohlson, CD93: recent advances and implications in disease, Curr. Drug Targets 13 (3) (2012) 411-420.

[46] S.F. Kingsmore, D.P. Vik, C.B. Kurtz, P. Leroy, B.F. Tack, J.H. Weis, M.F. Seldin, Genetic organization of complement receptor-related genes in the mouse, J. Exp. Med. 169 (4) (1989) 1479-1484.

[47] A.P. Spicer, M.F. Seldin, S.J. Gendler, Molecular cloning and chromosomal localization of the mouse decay-accelerating factor genes. Duplicated genes encode glycosylphosphatidylinositol-anchored and transmembrane forms, J. Immunol. (Baltimore, Md. 1950) 155 (6) (1995) 3079-3091.

[48] J. Chen, Y. Du, P. Ding, X. Zhang, L. Zhang, N. Wang, W. Hu, Mouse Cd59b but not Cd59a is upregulated to protect cells from complement attack in response to inflammatory stimulation, Genes Immun. 16 (7) (2015) 437-445, http://dx.doi.org/10.1038/gene.2015.29.

[49] A.C. Jacobson, J.H. Weis, Comparative functional evolution of human and mouse CR1 and CR2, J. Immunol. (Baltimore, Md. 1950) 181 (5) (2008) 2953-2959.

[50] I.Y. Pappworth, C. Hayes, J. Dimmick, B.P. Morgan, V.M. Holers, K.J. Marchbank, Mice expressing human CR1/CD35 have an enhanced humoral immune response to T-dependent antigens but fail to correct the effect of 
premature human CR2 expression, Immunobiology 217 (2) (2012) 147-157, http://dx.doi.org/10.1016/j.imbio.2011.06.001.

[51] Y.M. Qian, X. Qin, T. Miwa, X. Sun, J.A. Halperin, W.C. Song, Identification and functional characterization of a new gene encoding the mouse terminal complement inhibitor CD59, J. Immunol. (Baltimore, Md. 1950) 165 (5) (2000) 2528-2534.

[52] C.L. Harris, S.M. Hanna, M. Mizuno, D.S. Holt, K.J. Marchbank, B.P. Morgan, Characterization of the mouse analogues of CD59 using novel monoclonal antibodies: tissue distribution and functional comparison, Immunology 109 (1) (2003) 117-126.

[53] C. Picard, W. Al-Herz, A. Bousfiha, J.L. Casanova, T. Chatila, M.E. Conley, C. Cunningham-Rundles, A. Etzioni, S.M. Holland, C. Klein, S. Nonoyama, H.D. Ochs, E. Oksenhendler, J.M. Puck, K.E. Sullivan, M.L. Tang, J.L. Franco, H.B. Gaspar, Primary immunodeficiency diseases: an update on the classification from the international union of immunological societies expert committee for primary immunodeficiency 2015, J. Clin. Immunol. 35 (8) (2015) 696-726, http://dx.doi.org/10.1007/s10875-015-0201-1.

[54] K.R. Mayilyan, Complement genetics, deficiencies, and disease associations, Protein Cell 3 (7) (2012) 487-496, http://dx.doi.org/10.1007/s13238-012 2924-6.

[55] S.K. Nath, J.B. Harley, Y.H. Lee, Polymorphisms of complement receptor 1 and interleukin-10 genes and systemic lupus erythematosus: a meta-analysis, Hum. Genet. 118 (2) (2005) 225-234, http://dx.doi.org/10. 1007/s00439-005-0044-6.

[56] A. Etzioni, Defects in the leukocyte adhesion cascade, Clin. Rev. Allergy Immunol. 38 (1) (2010) 54-60, http://dx.doi.org/10.1007/s12016-009-81323.

[57] A. Jonsen, S.C. Nilsson, E. Ahlqvist, E. Svenungsson, I. Gunnarsson, K.G. Eriksson, A. Bengtsson, A. Zickert, M.L. Eloranta, L. Truedsson, L. Ronnblom, G. Nordmark, G. Sturfelt, A.M. Blom, Mutations in genes encoding complement inhibitors CD46 and CFH affect the age at nephritis onset in patients with systemic lupus erythematosus, Arthritis Res. Ther. 13 (6) (2011) R206, http://dx.doi.org/10.1186/ar3539.

[58] R.A. Brodsky, Paroxysmal nocturnal hemoglobinuria, Blood 124 (18) (2014) 2804-2811, http://dx.doi.org/10.1182/blood-2014-02-522128.

[59] B. Hochsmann, H. Schrezenmeier, Congenital CD59 deficiency, Hematol. Oncol. Clin. North Am. 29 (3) (2015) 495-507, http://dx.doi.org/10.1016/j. hoc.2015.01.006.

[60] A. Jimenez-Reinoso, A.V. Marin, M. Subias, A. Lopez-Lera, E. Roman-Ortiz, K Payne, C.S. Ma, G. Arbore, M. Kolev, S.J. Freeley, C. Kemper, S.G. Tangye, E. Fernandez-Malave, S. Rodriguez de Cordoba, M. Lopez-Trascasa, J.R. Regueiro, Human plasma C3 is essential for the development of memory B, but not T, lymphocytes, J. Allergy Clin. Immunol. (2017), http://dx.doi.org/ 10.1016/j.jaci.2017.09.037 [Epub ahead of print].

[61] Y. Okura, I. Kobayashi, M. Yamada, S. Sasaki, Y. Yamada, I. Kamioka, R. Kanai, Y. Takahashi, T. Ariga, Clinical characteristics and genotype-phenotype correlations in C3 deficiency, J. Allergy Clin. Immunol. 137 (2) (2016) 640-644, http://dx.doi.org/10.1016/j.jaci.2015.08.017, e1.

[62] M.J. Geerlings, E.K. de Jong, A.I. den Hollander, The complement system in age-related macular degeneration: a review of rare genetic variants and implications for personalized treatment, Mol. Immunol. 84 (2017) 65-76, http://dx.doi.org/10.1016/j.molimm.2016.11.016.

[63] R. Martinez-Barricarte, M. Heurich, A. Lopez-Perrote, A. Tortajada, S. Pinto, M. Lopez-Trascasa, P. Sanchez-Corral, B.P. Morgan, O. Llorca, C.L. Harris, S. Rodriguez de Cordoba, The molecular and structural bases for the association of complement C3 mutations with atypical hemolytic uremic syndrome, Mol. Immunol. 66 (2) (2015) 263-273, http://dx.doi.org/10.1016/ j.molimm.2015.03.248.

[64] R. Martinez-Barricarte, M. Heurich, F. Valdes-Canedo, E. Vazquez-Martul, E. Torreira, T. Montes, A. Tortajada, S. Pinto, M. Lopez-Trascasa, B.P. Morgan, O. Llorca, C.L. Harris, S. Rodriguez de Cordoba, Human C3 mutation reveals a mechanism of dense deposit disease pathogenesis and provides insights into complement activation and regulation, J. Clin. Invest. 120 (10) (2010) 3702-3712, http://dx.doi.org/10.1172/jci43343.

[65] K.M. Brown, E. Kondeatis, R.W. Vaughan, S.P. Kon, C.K. Farmer, J.D. Taylor, X. He, A. Johnston, C. Horsfield, B.J. Janssen, P. Gros, W. Zhou, S.H. Sacks, N.S Sheerin, Influence of donor C3 allotype on late renal-transplantation outcome, N. Engl. J. Med. 354 (19) (2006) 2014-2023, http://dx.doi.org/10. 1056/NEJMoa052825.

[66] D.M. Valero-Hervas, E. Sanchez-Zapardiel, M.J. Castro, F. Gallego-Bustos, F. Cambra, I. Justo, R. Laguna-Goya, C. Jimenez-Romero, E. Moreno, F. Lopez-Medrano, R. San Juan, M. Fernandez-Ruiz, J.M. Aguado, E. Paz-Artal, Complement C3F allotype synthesized by liver recipient modifies transplantation outcome independently from donor hepatic $\mathrm{C} 3$, Clin. Transpl. 31 (1) (2017), http://dx.doi.org/10.1111/ctr.12866.

[67] M. Goldberg, V. Fremeaux-Bacchi, P. Koch, Z. Fishelson, Y. Katz, A novel mutation in the C3 gene and recurrent invasive pneumococcal infection: a clue for vaccine development, Mol. Immunol. 48 (15-16) (2011) 1926-1931 http://dx.doi.org/10.1016/j.molimm.2011.05.020.

[68] L. Truedsson, Classical pathway deficiencies - a short analytical review, Mol. Immunol. 68 (1) (2015) 14-19, http://dx.doi.org/10.1016/j.molimm.2015. 05.007.

[69] R. Colobran, C. Franco-Jarava, A. Martin-Nalda, N. Baena, E. Gabau, N. Padilla, X. de la Cruz, R. Pujol-Borrell, D. Comas, P. Soler-Palacin, M. Hernandez-Gonzalez, Novel mutations causing C5 deficiency in three
North-African families, J. Clin. Immunol. 36 (4) (2016) 388-396, http://dx. doi.org/10.1007/s10875-016-0275-4.

[70] L. Schejbel, D. Fadnes, H. Permin, K.T. Lappegard, P. Garred, T.E. Mollnes, Primary complement C5 deficiencies - molecular characterization and clinical review of two families, Immunobiology 218 (10) (2013) 1304-1310, http://dx.doi.org/10.1016/j.imbio.2013.04.021.

[71] L. Skattum, M. van Deuren, T. van der Poll, L. Truedsson, Complement deficiency states and associated infections, Mol. Immunol. 48 (14) (2011) 1643-1655, http://dx.doi.org/10.1016/j.molimm.2011.05.001.

[72] E. Marcenaro, R. Augugliaro, M. Falco, R. Castriconi, S. Parolini, S. Sivori, E. Romeo, R. Millo, L. Moretta, C. Bottino, A. Moretta, CD59 is physically and functionally associated with natural cytotoxicity receptors and activates human NK cell-mediated cytotoxicity, Eur. J. Immunol. 33 (12) (2003) 3367-3376, http://dx.doi.org/10.1002/eji.200324425.

[73] C.M. Karsten, Y. Laumonnier, B. Eurich, F. Ender, K. Broker, S. Roy, A. Czabanska, T. Vollbrandt, J. Figge, J. Kohl, Monitoring and cell-specific deletion of C5aR1 using a novel floxed GFP-C5aR1 reporter knock-in mouse, J. Immunol. (Baltimore, Md. 1950) 194 (4) (2015) 1841-1855, http://dx.doi. org/10.4049/jimmunol.1401401.

[74] M.E. Fusakio, J.P. Mohammed, Y. Laumonnier, K. Hoebe, J. Kohl, J. Mattner, C5a regulates NKT and NK cell functions in sepsis, J. Immunol. (Baltimore, Md. 1950) 187 (11) (2011) 5805-5812, http://dx.doi.org/10.4049/jimmunol. 1100338.

[75] L. Wang, D. Halliday, P.M. Johnson, S.E. Christmas, Expression of complement regulatory proteins on human natural killer cell subsets, Immunol. Lett. 112 (2) (2007) 104-109, http://dx.doi.org/10.1016/j.imlet.2007.07.005.

[76] B. Coughlin, G. Schnabolk, K. Joseph, H. Raikwar, K. Kunchithapautham, K. Johnson, K. Moore, Y. Wang, B. Rohrer, Connecting the innate and adaptive immune responses in mouse choroidal neovascularization via the anaphylatoxin C5a and gammadeltaT-cells, Sci. Rep. 6 (2016) 23794, http:// dx.doi.org/10.1038/srep23794.

[77] C.M. Karsten, J. Kohl, The complement receptor CD46 tips the scales in T(H)1 self-control, Nat. Immunol. 11 (9) (2010) 775-777, http://dx.doi.org/10. 1038/ni0910-775.

[78] C. Kemper, A.C. Chan, J.M. Green, K.A. Brett, K.M. Murphy, J.P. Atkinson, Activation of human CD4+ cells with CD3 and CD46 induces a T-regulatory cell 1 phenotype, Nature 421 (6921) (2003) 388-392, http://dx.doi.org/10. 1038/nature01315.

[79] T. Miwa, L. Zhou, Y. Kimura, D. Kim, A. Bhandoola, W.C. Song, Complement-dependent T-cell lymphopenia caused by thymocyte deletion of the membrane complement regulator Crry, Blood 113 (12) (2009) 2684-2694, http://dx.doi.org/10.1182/blood-2008-05-157966.

[80] E.M. Fischer, A. Mouhoub, F. Maillet, V. Fremeaux-Bacchi, C. Krief, H. Gould, S. Berrih-Aknin, M.D. Kazatchkine, Expression of CD21 is developmentally regulated during thymic maturation of human T lymphocytes, Int. Immunol. 11 (11) (1999) 1841-1849.

[81] M.L. Pekalski, A.R. Garcia, R.C. Ferreira, D.B. Rainbow, D.J. Smyth, M. Mashar, J. Brady, N. Savinykh, X.C. Dopico, S. Mahmood, S. Duley, H.E. Stevens, N.M. Walker, A.J. Cutler, F. Waldron-Lynch, D.B. Dunger, C. Shannon-Lowe, A.J. Coles, J.L. Jones, C. Wallace, J.A. Todd, L.S. Wicker, Recent thymic emigrants produce antimicrobial IL-8, express complement receptors and are precursors of a tissue-homing Th8 lineage of memory cells, bioRxiv (2016), http://dx doi.org/10.1101/059535.

[82] M.G. Strainic, E.M. Shevach, F. An, F. Lin, M.E. Medof, Absence of signaling into CD4(+) cells via C3aR and C5aR enables autoinductive TGF-beta1 signaling and induction of Foxp3(+) regulatory T cells, Nat. Immunol. 14 (2) (2013) 162-171, http://dx.doi.org/10.1038/ni.2499.

[83] W. van der Touw, P. Cravedi, W.H. Kwan, E. Paz-Artal, M. Merad, P.S. Heeger, Cutting edge: receptors for C3a and C5a modulate stability of alloantigen-reactive induced regulatory T cells, J. Immunol. (Baltimore, Md. 1950) 190 (12) (2013) 5921-5925, http://dx.doi.org/10.4049/jimmunol. 1300847.

[84] C. Fang, X. Zhang, T. Miwa, W.C. Song, Complement promotes the development of inflammatory T-helper 17 cells through synergistic interaction with Toll-like receptor signaling and interleukin-6 production, Blood 114 (5) (2009) 1005-1015, http://dx.doi.org/10.1182/blood-2009-01198283.

[85] M. Hashimoto, K. Hirota, H. Yoshitomi, S. Maeda, S. Teradaira, S. Akizuki, P. Prieto-Martin, T. Nomura, N. Sakaguchi, J. Kohl, B. Heyman, M. Takahashi, T. Fujita, T. Mimori, S. Sakaguchi, Complement drives Th17 cell differentiation and triggers autoimmune arthritis, J. Exp. Med. 207 (6) (2010) 1135-1143. http://dx.doi.org/10.1084/jem.20092301.

[86] J. Liu, T. Miwa, B. Hilliard, Y. Chen, J.D. Lambris, A.D. Wells, W.C. Song, The complement inhibitory protein DAF (CD55) suppresses T cell immunity in vivo, J. Exp. Med. 201 (4) (2005) 567-577, http://dx.doi.org/10.1084/jem. 20040863.

[87] A.C. Tosello, F. Mary, M. Amiot, A. Bernard, D. Mary, Activation of T cells via CD55: recruitment of early components of the CD3-TCR pathway is required for IL-2 secretion, J. Inflamm. 48 (1) (1998) 13-27.

[88] A. Ghannam, J.L. Fauquert, C. Thomas, C. Kemper, C. Drouet, Human complement $\mathrm{C} 3$ deficiency: Th1 induction requires $\mathrm{T}$ cell-derived complement C3a and CD46 activation, Mol. Immunol. 58 (1) (2014) 98-107, http://dx.doi.org/10.1016/j.molimm.2013.11.010.

[89] P.T. Pekkarinen, K. Vaali, S. Junnikkala, L.H. Rossi, H. Tuovinen, S. Meri, O. Vaarala, T.P. Arstila, A functional complement system is required for normal 
T helper cell differentiation, Immunobiology 216 (6) (2011) 737-743, http:// dx.doi.org/10.1016/j.imbio.2010.10.004.

[90] G. Le Friec, D. Sheppard, P. Whiteman, C.M. Karsten, S.A. Shamoun, A. Laing, L. Bugeon, M.J. Dallman, T. Melchionna, C. Chillakuri, R.A. Smith, C. Drouet, L. Couzi, V. Fremeaux-Bacchi, J. Kohl, S.N. Waddington, J.M. McDonnell, A. Baker, P.A. Handford, S.M. Lea, C. Kemper, The CD46-Jagged1 interaction is critical for human TH1 immunity, Nat. Immunol. 13 (12) (2012) 1213-1221, http://dx.doi.org/10.1038/ni.2454.

[91] S. Tilib Shamoun, G. Le Friec, N. Spinner, C. Kemper, A.J. Baker, Immune dysregulation in Alagille syndrome: a new feature of the evolving phenotype, Clin. Res. Hepatol. Gastroenterol. 39 (5) (2015) 566-569, http:// dx.doi.org/10.1016/j.clinre.2015.02.003.

[92] N. Remus, J. Reichenbach, C. Picard, C. Rietschel, P. Wood, D. Lammas, D.S. Kumararatne, J.L. Casanova, Impaired interferon gamma-mediated immunity and susceptibility to mycobacterial infection in childhood, Pediatr. Res. 50 (1) (2001) 8-13, http://dx.doi.org/10.1203/00006450200107000-00005.

[93] S.M. Truscott, G. Abate, J.D. Price, C. Kemper, J.P. Atkinson, D.F. Hoft, CD46 engagement on human $\mathrm{CD} 4+\mathrm{T}$ cells produces $\mathrm{T}$ regulatory type 1-like regulation of antimycobacterial T cell responses, Infect. Immun. 78 (12) (2010) 5295-5306, http://dx.doi.org/10.1128/iai.00513-10.

[94] M. Kopf, B. Abel, A. Gallimore, M. Carroll, M.F. Bachmann, Complement component $\mathrm{C} 3$ promotes T-cell priming and lung migration to control acute influenza virus infection, Nat. Med. 8 (4) (2002) 373-378, http://dx.doi.org/ 10.1038/nm0402-373.

[95] M. Suresh, H. Molina, M.S. Salvato, D. Mastellos, J.D. Lambris, M. Sandor Complement component 3 is required for optimal expansion of CD8 T cells during a systemic viral infection, J. Immunol. (Baltimore, Md. 1950) 170 (2) (2003) 788-794.

[96] A.H. Kim, I.D. Dimitriou, M.C. Holland, D. Mastellos, Y.M. Mueller, J.D. Altman, J.D. Lambris, P.D. Katsikis, Complement C5a receptor is essential for the optimal generation of antiviral CD8+ T cell responses, J. Immunol. (Baltimore, Md. 1950) 173 (4) (2004) 2524-2529.

[97] Y. Wang, S.N. Sun, Q. Liu, Y.Y. Yu, J. Guo, K. Wang, B.C. Xing, Q.F. Zheng, M.J. Campa, E.F. Patz Jr., S.Y. Li, Y.W. He, Autocrine complement inhibits IL10-dependent T-cell-mediated antitumor immunity to promote tumor progression, Cancer Discov. 6 (9) (2016) 1022-1035, http://dx.doi.org/10. 1158/2159-8290.cd-15-1412.

[98] A. Jimenez-Reinoso, A.V. Marin, J.R. Regueiro, Complement in basic processes of the cell, Mol. Immunol. 84 (2017) 10-16, http://dx.doi.org/10. 1016/j.molimm.2016.11.011.

[99] P.W. Dempsey, M.E. Allison, S. Akkaraju, C.C. Goodnow, D.T. Fearon, C3d of complement as a molecular adjuvant: bridging innate and acquired immunity, Sci. (N. Y., N.Y.) 271 (5247) (1996) 348-350.

[100] A. Cherukuri, P.C. Cheng, S.K. Pierce, The role of the CD19/CD21 complex in B cell processing and presentation of complement-tagged antigens, J. Immunol. (Baltimore, Md. 1950) 167 (1) (2001) 163-172.

[101] T. Lyubchenko, J.M. Dal Porto, V.M. Holers, J.C. Cambier, Cutting edge: complement (C3d)-linked antigens break B cell anergy, J. Immunol. (Baltimore, Md. 1950) 179 (5) (2007) 2695-2699.
[102] C.J. Del Nagro, R.V. Kolla, R.C. Rickert, A critical role for complement C3d and the B cell coreceptor (CD19/CD21) complex in the initiation of inflammatory arthritis, J. Immunol. (Baltimore, Md. 1950) 175 (8) (2005) 5379-5389.

[103] L.C. Hundgeburth, M. Wunsch, D. Rovituso, M.S. Recks, K. Addicks, P.V. Lehmann, S. Kuerten, The complement system contributes to the pathology of experimental autoimmune encephalomyelitis by triggering demyelination and modifying the antigen-specific $T$ and $B$ cell response, Clin. Immunol. (Orlando, Fla.) 146 (3) (2013) 155-164, http://dx.doi.org/10. 1016/j.clim.2012.12.007.

[104] A. Ghannam, M. Pernollet, J.L. Fauquert, N. Monnier, D. Ponard, M.B. Villiers, J. Peguet-Navarro, A. Tridon, J. Lunardi, D. Gerlier, C. Drouet, Human C3 deficiency associated with impairments in dendritic cell differentiation, memory B cells, and regulatory T cells, J. Immunol. (Baltimore, Md. 1950) 181 (7) (2008) 5158-5166.

[105] H.T. Maecker, S. Levy, Normal lymphocyte development but delayed humoral immune response in CD81-null mice, J. Exp. Med. 185 (8) (1997) 1505-1510.

[106] E.N. Tsitsikov, J.C. Gutierrez-Ramos, R.S. Geha, Impaired CD19 expression and signaling, enhanced antibody response to type II T independent antigen and reduction of B-1 cells in CD81-deficient mice, Proc. Natl. Acad. Sci. U. S. A. 94 (20) (1997) 10844-10849.

[107] M.C. van Zelm, I. Reisli, M. van der Burg, D. Castano, C.J. van Noesel, M.J. van Tol, C. Woellner, B. Grimbacher, P.J. Patino, J.J. van Dongen, J.L. Franco, An antibody-deficiency syndrome due to mutations in the CD19 gene, N. Engl. J. Med. 354 (18) (2006) 1901-1912, http://dx.doi.org/10.1056/NEJMoa051568.

[108] M.C. van Zelm, J. Smet, B. Adams, F. Mascart, L. Schandene, F. Janssen, A. Ferster, C.C. Kuo, S. Levy, J.J. van Dongen, M. van der Burg, CD81 gene defect in humans disrupts CD19 complex formation and leads to antibody deficiency, J. Clin. Invest. 120 (4) (2010) 1265-1274, http://dx.doi.org/10. $1172 /$ jci39748.

[109] R. Roozendaal, M.C. Carroll, Complement receptors CD21 and CD35 in humoral immunity, Immunol. Rev. 219 (2007) 157-166, http://dx.doi.org/ 10.1111/j.1600-065X.2007.00556.x.

[110] S.R. Brodeur, F. Angelini, L.B. Bacharier, A.M. Blom, E. Mizoguchi, H. Fujiwara, A. Plebani, L.D. Notarangelo, B. Dahlback, E. Tsitsikov, R.S. Geha, C4b-binding protein (C4BP) activates B cells through the CD40 receptor, Immunity 18 (6) (2003) 837-848.

[111] K.T. Williams, S.P. Young, A. Negus, L.S. Young, D.H. Adams, S.C. Afford, C4b binding protein binds to CD154 preventing CD40 mediated cholangiocyte apoptosis: a novel link between complement and epithelial cell survival, PloS One 2 (1) (2007) e159, http://dx.doi.org/10.1371/journal.pone.0000159.

[112] H.H. Jabara, F. Angelini, S.R. Brodeur, R.S. Geha, Ligation of CD46 to CD40 inhibits CD40 signaling in B cells, Int. Immunol. 23 (3) (2011) 215-221, http://dx.doi.org/10.1093/intimm/dxq474. 